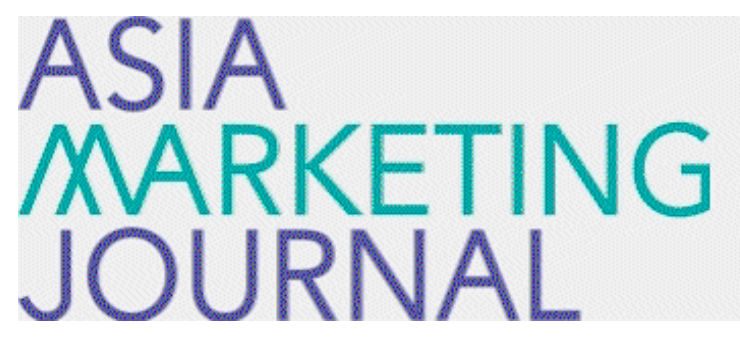

ASIA MARKETING JOURNAL

Volume 21 | Issue 4

Article 6

$1-31-2020$

\title{
ASIA MARKETING JOURNAL Vol.21 No.4 목차
}

Follow this and additional works at: https://amj.kma.re.kr/journal

Part of the Marketing Commons

\section{Recommended Citation}

(2020) "ASIA MARKETING JOURNAL Vol.21 No.4 목차," Asia Marketing Journal: Vol. 21 : Iss. 4 , Article 6. Available at: https://doi.org/10.53728/2765-6500.1348

This Article is brought to you for free and open access by Asia Marketing Journal. It has been accepted for inclusion in Asia Marketing Journal by an authorized editor of Asia Marketing Journal. 


\section{ASAMARKKETNG JOURNAL}

\section{Vol. 21 No. 04 January 2020}

\section{$<$ Research Paper $>$}

What Brings Customer Gapjil? The Intertwined Effects of Perceived Economic Mobility, Self-Other Referent Priming, and Temporal Focus

The Causes of Guilt in Ready-meal Users:

A Focus on Cooking Instructions and Consumers' Health Locus of Control Hyunsook Shin · Dongmin Lee · Jeeyoung Lim · Junghoon Moon

The Effect of Product Experience Through Virtual Reality on Product Evaluation Eunmi Jeon · Youngjee Han · Hyunjin Woo

\section{$<$ Research Note>}

Liability of Newness, Startup Capabilities and Crowdfunding Success

The Effect of Population-Level Learning on Entry Likelihood in the Mobile Game Industry Dusan Seong · Sahangsoon Kim 